\title{
EMPRESARIADO, INSTITUIÇÕES DEMOCRÁTICAS E REFORMA POLÍTICA
}

\author{
Paulo Roberto Neves Costa
}

\begin{abstract}
RESUMO
Este texto analisa como os presidentes de 40 entidades de representação do empresariado brasileiro avaliavam o funcionamento das instituições democráticas e a perspectiva da reforma política, entre os anos de 2004 e 2005. Os dados foram agregados de duas formas: de um lado, o conjunto das entidades e, de outro, pela natureza da entidade (sindical ou associativa), pelo setor (indústria, comércio, agricultura, finanças etc.) e pela localização ou abrangência (entidades estaduais, discriminadas pelas regiões, e nacionais). Os objetivos são, por um lado, defender a importância da mobilização deste tipo de variável na análise das características do empresariado e de sua ação política e, por outro lado, verificar o grau de homogeneidade das opiniões e posturas frente aos seguintes aspectos: o grau de adesão e a opinião acerca da democracia enquanto regime político; a avaliação das instituições democráticas em funcionamento; a atribuição de importância política aos grupos sociais e às instituições políticas; a visão a respeito da ação política dos empresários frente aos poderes constituídos; por fim, a posição frente à reforma política. Com isso, pretendemos estabelecer elementos para futuras análises dos padrões de ação política dos empresários face à questão das instituições políticas e do futuro da democracia no Brasil.
\end{abstract}

PALAVRAS-CHAVE: empresariado; reforma política; corporativismo; democracia.

\section{INTRODUÇÃO}

O objetivo deste trabalho é fazer um ensaio analítico sobre os valores e percepções do empresariado brasileiro no que diz respeito às instituições políticas democráticas vigentes e a possibilidade de sua transformação. Trata-se de pesquisa na qual procuramos verificar quais são as concepções sobre a democracia, as instituições políticas, a necessidade e o processo de transformação dessas instituições e sobre o possível impacto das ações concretas do empresariado frente a esse processo e ao funcionamento do regime político democrático ${ }^{1}$. O critério utilizado para a escolha dos entrevista-

${ }^{1}$ A pesquisa Empresariado, instituições e democracia: a questão da reforma política teve apoio do Conselho Nacional de Desenvolvimento Científico e Tecnológico (CNPq) e da Federação do Comércio do Estado de São Paulo (Fecomércio). Expresso os meus agradecimentos a Emerson Cervi pelo apoio no tratamento estatístico dos dados e a Karla Gobbo, Nadida Mafouhz e Júlio Gouveia pelo trabalho de aplicação dos questionários e processamento dos dados. Resultados parciais desta pesquisa foram apresentados no III Congresso da Associação Latino-Americana de Ciência Política (Alacip), realizado de 4 a 6 de setembro de 2006 em Campinas (São Paulo), e no XXX Encontro Nacional da Associação Nacional de Pesquisa e PósGraduação em Ciências Sociais (Anpocs), realizado entre 24 e 28 de outubro de 2006, em Caxambu (Minas Gerais). dos foi o da representação política. Para tanto, contemplamos os presidentes de algumas entidades de representação do empresariado, em âmbito nacional, entre 2004 e 2005. Por meio da aplicação de um questionário, procuramos captar a opinião acerca das particularidades e das prerrogativas da democracia, dos poderes Executivo, Legislativo e Judiciário, das eleições e do sistema eleitoral, bem como das instituições representativas, em especial os partidos políticos, os sindicatos e as associações, permitindo comparações com trabalhos especificamente sobre o empresariado brasileiro e também com pesquisas de opinião feitas entre a população em geral. Como os questionários foram enviados por correio e as respostas, voluntárias, não é possível identificar nas respostas apresentadas aqui uma amostra representativa da totalidade de líderes empresariais brasileiros. Apesar de não pretender fazer nenhuma inferência em relação ao conjunto de representantes do setor, o trabalho é importante pela sua proposta de agenda de pesquisa e para demonstrar como pensam a respeito da democracia os empresários que responderam a pesquisa ${ }^{2}$.

2 Convém destacar que a grande maioria dos questionários foi respondida antes das revelações das comissões parlamentares de inquérito (CPIs) que funcionaram no Congresso Nacional em 2005.

Rev. Sociol. Polít., Curitiba, 28, p. 99-116, jun. 2007 
Com isso, pretendemos verificar as condições e as características de uma dimensão importante, ainda que não exclusiva ou determinante, para a compreensão do comportamento do empresariado frente ao funcionamento da democracia, ou seja, a sua concepção acerca da democracia e do regime democrático, bem como verificar o grau de homogeneidade das opiniões dos presidentes contemplados pela pesquisa ${ }^{3}$. Enfim, embora esta pesquisa seja sobre opiniões e valores políticos, seus resultados permitirão considerar uma variável importante no estudo do processo de definição dos padrões de ação política do empresariado, bem como o grau e a forma de sua adesão às instituições políticas democráticas, pelo menos dos presidentes das entidades contempladas pela pesquisa. Isso ganha maior relevância quando se coloca no horizonte político nacional a questão da reforma política.

Alguns esclarecimentos de ordem metodológica fazem-se necessários. Em primeiro lugar, nosso objetivo não é fazer um levantamento exaustivo das opiniões do empresariado sobre a democracia e seu funcionamento no Brasil, mas, sobretudo, enfatizar a importância da mobilização desse tipo de questão e de variáveis para a análise do empresariado, sua constituição enquanto grupo social, seus padrões de ação política e sua relação com as instituições democráticas. Portanto, a parte empírica deste trabalho e os seus resultados servem mais como forma de defender a necessidade deste tipo de estudo do que buscar ter um quadro efetivamente representativo da posição do conjunto dos empresários frente à democracia.

Em segundo lugar, se o conjunto das entidades aqui consideradas não permite generalizações para as inúmeras instituições que, de uma forma ou de outra, buscam representar interesses relacionados às atividades empresariais, há um as-

3 Até mesmo estudos clássicos no campo da cultura política enfatizam a importância de verificar-se as atitudes tanto dos cidadãos comuns quanto das elites políticas da sociedade (ALMOND \& VERBA, 1989), entre os quais entendemos que podem ser considerados os presidentes de entidades de representação empresarial, menos pelo poder econômico ou político e mais pelo exercício da representação política de um dado coletivo. Por sua vez, Ingelhart (1988) sugere a importância de considerar não apenas os aspectos econômicos e políticos do que chama de "burguesia”, mas também seus aspectos culturais, suas atitudes e valores, dado que a modernização das relações de ordem econômica não pode prescindir de uma cultura política favorável à democracia para o seu sucesso. pecto que identifica todos os entrevistados: tratase de empresários que ocupam cargos de direção de entidades de representação empresarial. Além de remeter à questão teórica da representação e ao problema das particularidades das formas de articulação entre sociedade e Estado no Brasil, a dimensão empírica deste tipo de estudo implica também dificuldades de natureza metodológica que em muito transcendem os objetivos fundamentais deste artigo e da pesquisa que o sustenta. Enfim, as inferências aqui apresentadas referem-se estritamente a essas entidades, mas permitem-nos alcançar os objetivos pretendidos.

Em terceiro lugar, a problemática aqui adotada inevitavelmente remete à questão do poder político, suposto ou comprovado, de cada entidade. Isso nos coloca diante de outras questões igualmente teóricas e metodológicas, as quais devem ser tratadas. O poder político das entidades em geral é inferido a partir de variáveis econômicas, tais como o peso econômico da unidade federativa a qual pertence, a importância da atividade representada na economia, a parcela do produto interno bruto (PIB) que as empresas supostamente representadas pela entidade representam etc. Tais variáveis são sociologicamente precárias e, quando tomadas acriticamente, mais confundem do que esclarecem ${ }^{4}$. A atribuição de representatividade por critérios econômicos, bastante corrente na imprensa e entre as próprias entidades empresariais, não pode ser desconsiderada, mas não pode ser pressuposta antes da averiguação de sua ocorrência em uma dada situação, pois uma entidade avaliada como muito importante pode se omitir ou até mesmo ser mal-sucedida em suas demandas.

Enfim, o peso político de uma entidade, em especial no que tange à questão do funcionamento das instituições políticas, não pode ser considerado apenas a partir de variáveis econômicas, nem atribuído ou simplesmente pressuposto, mas sim averiguado quando de sua ocorrência. Essa é uma agenda de pesquisa ainda pouco presente nos estudos sobre empresariado no Brasil. Daí a necessidade de pesquisas que se voltem para a ação política desse grupo em relação a questões importantes da ordem político-institucional da democracia, nos processos normais de seu funcio-

\footnotetext{
4 Sabemos, por exemplo, que estados menos importantes na distribuição do desenvolvimento econômico em geral têm importante presença na direção das entidades sindicais
} nacionais (confederações). 
namento ou em momentos de reforma das instituições políticas. Entendemos que o estudo das percepções e avaliações pode fornecer-nos um elemento comparativo entre, de um lado, o posicionamento prévio e as idéias e, de outro, as ações ou mesmo a sua falta ${ }^{5}$.

Isso é mais relevante ainda quando não estamos propriamente analisando, neste momento, a ação política $^{6}$. Nossa preocupação está voltada para as percepções e avaliações a respeito das instituições políticas, que, além de possuírem em si relevância sociológica, estão sendo aqui consideradas como elementos que podem contribuir para a construção de estratégias mais eficazes para estudos futuros das ações políticas propriamente ditas.

Tais questões sugerem a necessidade de descrever as particularidades do conjunto de entidades aqui considerado. A Tabela 1 mostra que há várias instituições que poderiam ser consideradas importantes, mesmo se adotássemos exclusivamente as variáveis econômicas acima mencionadas, seja pelo setor que representam, seja pela importância econômica de sua região, seja pela sua presença em processos importantes da história do país ${ }^{7}$. A distribuição das entidades por atividade deu-se de maneira equilibrada, assim como por estados e regiões. Quanto à natureza, sindical ou associativa, nosso objeto contempla também a presença desses dois tipos de entidade ${ }^{8}$.

Se as variáveis de natureza econômica não são satisfatórias nem propriamente adequadas para os nossos objetivos, é necessário estabelecer com pre-

\footnotetext{
5 Sobre esse aspecto, ver Costa (2003; 2005a; 2005b).

6 Essa questão foi aqui apenas parcialmente contemplada e será tratada mais adiante.

7 Como pode ser observado na Tabela 1, além de indústria, comércio e serviços e agricultura, estão presentes os setores de infra-estrutura, indústria química e financeiro. Estão presentes também entidades de renome, como a Federação das Indústrias do Estado de São Paulo (Fiesp), a Confederação Nacional da Indústria (CNI), a Federação Brasileira de Bancos (Febraban), a Associação Comercial de São Paulo (ACSP), a Associação Brasileira da Infra-estrutura e Indústrias de Base (Abdib), entre outras.

8 Com a expressão “associativa” referimo-nos às diversas associações que não são regidas pela legislação sindical que regula a representação das categorias econômicas e profissionais e que, portanto, decorrem da disposição dos interessados na sua constituição e não possuem nenhum tipo compulsório de contribuição, como ocorre com as entidades sindicais (sindicatos, federações e confederações).
}

cisão o modo de tratamento dos dados obtidos. Considerando as particularidades da atividade empresarial e das formas de representação corporativa no Brasil, entendemos que, embora os dados permitam diferentes tipos de agregação, tomaremos os resultados da pesquisa a partir de dois recortes:

1- O conjunto total das entidades (ver Tabela 1);

2- Outras formas de agregação das entidades, a saber:

a. por setores, agrupados em i) indústria, ii) comércio e serviços e iii) outros ${ }^{9}$;

b. por natureza da entidade, agrupados em entidades i) sindicais (federações e confederações) e ii) associativas;

c. por região ou abrangência, no caso, i) Sul, ii) Sudeste, iii) outras regiões (Centro-Oeste, Norte e Nordeste) e iv) nacionais.

Dessa forma, foram contempladas 15 entidades exclusivamente da indústria (36\%), treze de comércio e serviços (33\%) e 12 de outros setores (31\%). Quando consideramos a distribuição por região, temos sete entidades do Sul (18\%), cinco do Sudeste (15\%), dezenove de outras regiões $(49 \%)$ e nove entidades nacionais $(18 \%)^{10}$. Por fim, distinguimos as entidades sindicais de primeiro (sindicatos), segundo (federações) e terceiro (confederações) graus, das entidades associativas de diversos setores. Assim, quanto à natureza, temos 33 entidades sindicais (85\%) e sete associativas $(15 \%)^{11}$.

9 Nesse grupo enquadram-se entidades ligadas ao setor financeiro e à propriedade rural e também as associações comerciais, dado que estas em geral identificam-se como representantes de diversos setores e não apenas do comércio, como geralmente se associa (cf. Tabela 1).

10 Entre os estados não contemplados estão Acre, Alagoas, Amapá, Espírito Santo, Mato Grosso, Pará, Piauí, Tocantins e Rio de Janeiro. A ausência de entidades do Rio de Janeiro deveu-se a um aspecto da própria pesquisa, ou seja, a disposição de os presidentes das entidades responderem ao questionário. De quase cem entidades contatadas, apenas as que constam da Tabela 1 dispuseram-se a participar.

11 Além da dificuldade em obter o retorno dos questionários acima mencionada, observamos também que o peso maior das entidades sindicais de segundo grau, as federações, não deixa de estar relacionado ao fato de que elas são efetivamente mais numerosas na representação empresarial em relação àquelas de terceiro grau (confederações) e às entidades associativas nacionais. 


\begin{tabular}{|c|c|c|}
\hline & ENTIDADES & SETOR REPRESENTADO \\
\hline 1. & Associação Br asileir a da Indústria Química & Indústria química \\
\hline 2. & Associação Brasileira da Infra-estutura e Indústrias de Base & Infra-estrutura \\
\hline 3. & Associação Nacional das Instituiçốes do Mercado Fin anceiro & Setor fin anceiro \\
\hline 4. & $\begin{array}{c}\text { Associação Nacional das Irstituiçốes de C rédito e } \\
\text { Investimentos }\end{array}$ & Instituiçốes de crédito e bancos \\
\hline 5. & Associaçãa Comer cial de Minas Gerais & $\begin{array}{c}\text { Comércio, indústria, agronegócio e prestação de } \\
\text { serviços }\end{array}$ \\
\hline 6. & Associação Comercial do Paraná & Comércio e serviços \\
\hline 7. & Associação Comercial de São Paulo & $\begin{array}{l}\text { Todos } \alpha \text { setores de atividade e empresas de } \\
\text { todos } \alpha \text { portes }\end{array}$ \\
\hline 8. & Confe deração da Agricultura e Pecuária no Brasil & Produtores rurais brasileiros \\
\hline 9. & Confeder ação $\mathrm{N}$ acional das Irstituiçốes Fin anceir as & $\begin{array}{c}\text { Entidades repres entativas do sistem a fin ance iro } \\
\text { nacional }\end{array}$ \\
\hline 10. & Confe der ação Nacional do Comércio & Comércio \\
\hline 11. & Federação Brasileira dos Bancos & Setor bancário \\
\hline 12. & Feder ação da Agricultura do Estado do Paraíba & Empresários de trarsporte e produtores rurais \\
\hline 13. & Federação da Agricultura do Estado do Paraná & Produtores rurais \\
\hline 14. & Federação da Indústria do Estado do Amazonas & $\begin{array}{l}\text { Indístrias: eletro-eletrônico, veiculos de duas } \\
\text { rodas, informática, produtos de base florestal }\end{array}$ \\
\hline 15. & F ederação da Indústria do Estado do Ceará & $\begin{array}{l}\text { Indústrias têxtil, confecçốes, gráfica, papel e } \\
\text { papelẫo, corstruçẩo chuil, miner ais nâo metálicos }\end{array}$ \\
\hline 16. & Fe deraçấo das Indústria do Estado do Mato Gross o do Sul & $\begin{array}{c}\text { Setores da indústria de alimentos, vestuário, } \\
\text { mobiliário, açúcar e álcool, cerâmico, panific ação, } \\
\text { metalurgia, grático }\end{array}$ \\
\hline 17. & F ederação das Indús tias do Estado da Bahia & Indústia \\
\hline 18. & Federação das Indístrias do Estado de Goiás & Indústia \\
\hline 19. & Feder ação das Indústias do Estado de Pernambuco & Indústia \\
\hline 20. & Federação das Indístrias do Estado de Ror aima & $\begin{array}{c}\text { Madeir eiro, agro-industrial, gráfico, constr ução civil, } \\
\text { terraplanagem, alimentos }\end{array}$ \\
\hline 21. & Federaçãa das Indústrias do Estado de Rondônia & $\begin{array}{c}\text { Corstrução chuil, indústria madeireira, alimentos, } \\
\text { vestuário, frigorífico }\end{array}$ \\
\hline 22. & Federação das Indústias do Estado do Maranhão & Setor industrial, em todos $\alpha$ ramos \\
\hline 23. & Feder ação das Indíztrias do Estado do Paraná & Indústia \\
\hline 24. & Feder ação das Indístrias do Rio Grande do Norte & Indústia \\
\hline 25. & Feder ação das Indústrias do Rio Grande do Sul & Indústia \\
\hline 26. & Feder ação das Indístrias do Estado de São Paulo & Indústia \\
\hline 27. & $\begin{array}{c}\text { Feder ação do Comércio de Bens e de Senviços do Estado do } \\
\text { Rio Grande do Sul }\end{array}$ & Empresários do comércio de bers e senviços \\
\hline 28. & Federação do Comér cio de Minas Gerais & Comércio e serviços \\
\hline 29. & Feder ação do Comér cio do Estado da Bahia & Comércio e serviços \\
\hline 30. & Feder ação do Comércio do Estado de Goiás & Comércio e serviços \\
\hline 31. & Federação do C omércio do Estado de Santa Catarina & Comércio de bens, serviços e turismo \\
\hline 32. & Feder ação do Comér cio do Estado de São Paulo & Comércio e serviços \\
\hline 33. & Feder ação do Comér cio do Distrito Federal & Comér cio e senviços, saúde, turismo, hos pitalidade \\
\hline 34. & Federação do Comércio do Estado de Rondônia & $\begin{array}{l}\text { Comércio e serviços, incluindo na sua maior parte } \\
\text { "micro" e pequenos empresários }\end{array}$ \\
\hline 35. & Feder ação do Comércio do Estado de Sergipe & Comércio, senviços e turismo \\
\hline 36. & F ederação do Comércio do Estado do Mar anhão & Comércio de bens, serviços e turismo \\
\hline 37. & Federação do Comércio do Estado do Mato Grosso do Sul & Comércio e ger enciamento \\
\hline 38. & Feder ação do Comércio do Estado do Paraná & $\begin{array}{c}\text { Empresários dosegmento do comércio de bers. } \\
\text { produtos e senviços }\end{array}$ \\
\hline 39. & Feder ação do Comércio do Estado de Roraima & $\begin{array}{c}\text { Comercio e senviços, incluindo na sua maior parte } \\
\text { "micro" e pequenas empresários }\end{array}$ \\
\hline 40. & $\begin{array}{l}\text { Feder ação Nacional das Empresas de Serviços Contábeis, } \\
\text { Assessoramento, Perícias, Informaçốes e Pesquisas }\end{array}$ & $\begin{array}{c}\text { Empresas contábeis em geral e empressas de } \\
\text { assessoramento, perícias, informaçốes e } \\
\text { pesquisas }\end{array}$ \\
\hline
\end{tabular}

NOTA: a identificação dos setores representados foi feita pelos próprios respondentes. 
Em suma, levando em conta as características da representação empresarial e os estudos sobre empresariado no Brasil, verifica-se que foram contempladas entidades de abrangência nacional e estadual, entidades estaduais com importância nacional, entidades que representam regiões economicamente mais e menos desenvolvidas e entidades associativas e sindicais. E, como foi dito acima, entendemos que a base empírica e o seu tratamento dão conta dos nossos objetivos, que é, em primeiro lugar, chamar a atenção para a necessidade de estudar a relação entre empresários e instituições democráticas, seja para analisar as características deste grupo social, seja enquanto forma de pensar as características destas instituições; em segundo lugar, defender a importância da apreensão das formas de avaliação sobre essas instituições na construção de análises voltadas para a ação política do empresariado.

Ainda que dentro dos limites de nosso objeto, com esse procedimento pretendemos verificar tanto o posicionamento do conjunto das entidades quanto o grau de homogeneidade entre as respostas e as possíveis correlações entre as particularidades acima discriminadas e as posições e avaliações dos respondentes. Por fim, os resultados serão tratados a partir das seguintes questões: 1) o grau de adesão e a avaliação acerca da democracia enquanto forma de regime político; 2) a avaliação sobre as instituições democráticas em funcionamento; 3) o peso político atribuído aos grupos sociais e às instituições políticas; 4) os padrões de ação dos empresários frente aos poderes constituídos e 5) a posição frente à reforma política. As inferências e conclusões serão apresentadas no final deste texto.

\section{O GRAU DE ADESÃO À DEMOCRACIAE A CONCEPÇÃO DE REGIME DEMOCRÁTICO}

Considerando o conjunto das entidades, é praticamente unânime entre os entrevistados a convicção de que a democracia é sempre a melhor forma de funcionamento do Estado e a melhor também para os interesses do empresariado. Embora seja quase unânime a idéia de que o fim do regime democrático não é aceitável em hipótese alguma, quando colocados diante de possíveis situações que pudessem justificar o fim da democracia, o conjunto dos respondentes reagiram da seguinte forma: $18 \%$ concordam que isso deveria ocorrer se houver ameaça generalizada à propriedade privada, $15 \%$ se houver uma crise econômi- ca aguda ou descontrole da corrupção, 18\% se o Estado for ameaçado pelo crime organizado e apenas um Presidente considera tal possibilidade diante da quebra das hierarquias nas instituições militares.

Quando instados a avaliar as características da democracia, os presidentes são quase unânimes em declarar que a grande vantagem da democracia é poder eleger os governantes. Embora essa porcentagem caia para em torno de $85 \%$ quando se afirma que a grande vantagem da democracia seria a participação do maior número de pessoas nas decisões, apenas menos de um quarto dos presidentes entende que o maior problema da democracia seria os excessos de participação popular que ela gera. Entre os aspectos mais prejudiciais à democracia foram apontados, em ordem decrescente, a corrupção, a falta de educação para a população e a “desordem social”. Além disso, há o entendimento de que tais aspectos seriam mais prejudiciais do que as características das instituições ligadas ao processo de representação (partidos, sindicatos e sistema eleitoral).

Quanto à consolidação da democracia no Brasil, as opiniões dividem-se ao meio. Em relação a esse aspecto, a desagregação por setor não revela grandes diferenças, mas as entidades associativas estão mais convencidas do que as sindicais de que a democracia no Brasil está consolidada, o mesmo acontecendo entre as entidades do Sudeste, do Sul e nacionais em relação às entidades das outras regiões ${ }^{12}$.

Mais de dois terços dos presidentes pensa que a presença de empresários nos cargos públicos, técnicos e eletivos é fundamental para o sucesso da democracia mas, quando desagregamos os dados, essa porcentagem cai para $50 \%$ nas entidades associativas e nas entidades do Sudeste.

\section{O FUNCIONAMENTO DAS INSTITUI- ÇÕES DEMOCRÁTICAS NO BRASIL}

Quando perguntados sobre a relação entre os poderes Executivo e Legislativo em âmbito federal, praticamente todos concordam que este deveria ser mais autônomo em relação ao primeiro. Quanto ao grau de confiança nos poderes, enquanto instituições, pouco menos de $20 \%$ declararam

12 Dessas entidades, 63\% discordam da idéia de que a democracia no Brasil está consolidada e é forte. 
não confiar no Legislativo federal e no Executivo federal. Mas, entre as entidades associativas tal confiança cai para a metade. Somente metade dos respondentes concorda que o poder Legislativo federal deve ter maior interferência na política econômica. Nesse aspecto, a concordância aumenta para dois terços nas entidades nacionais.

Sobre o poder Judiciário, menos de $10 \%$ entendem que esse poder funciona de maneira satisfatória, mas essa situação inverte-se quando se trata da sua importância para a sustentação da democracia no Brasil. Todos entendem que o Judiciário deve passar por uma reforma interna e dois terços entendem que esse poder também deveria ser objeto da reforma política. Mais de $80 \%$ acham que o poder Judiciário deve ter alguma forma de controle externo.

Há quase unanimidade em relação à importância dos partidos políticos, nos âmbitos federal, estadual e municipal, para o bom funcionamento da democracia. Dois terços entendem que a questão do número de partidos é importante para o funcionamento da democracia brasileira. Mais de $80 \%$ declararam que tanto o exercício do governo quanto da oposição deve ter um caráter fortemente partidário. Mais de $70 \%$ entendem que a atuação dos lobbies não é prejudicial à democracia brasileira. Pouco mais de $50 \%$ entendem que a reeleição para os cargos do poder Executivo foi uma boa medida para a democracia no Brasil. Quanto a esse aspecto, a concordância sobe para quase dois terços nas entidades da indústria e cai para menos de $50 \%$ nas entidades do comércio, sendo que, por região, enquanto nas entidades do Sudeste sobe para 83\%, cai para $43 \%$ nas entidades do Sul.
Dois terços dos presidentes avaliam que, de um modo geral, o funcionamento das instituições políticas é favorável à manutenção de nossa democracia. Mas, quando perguntados sobre as instituições relacionadas à política econômica, mais de dois terços discordam de que o bom funcionamento dessas instituições é mais importante do que o bom funcionamento do Congresso Nacional e dos partidos políticos, sendo que nas entidades do Sul e do Sudeste e, por setor, da indústria, tal discordância é ainda mais forte, mas cai para menos de $50 \%$ entre as entidades do comércio e dos serviços. De um modo geral, mais de $80 \%$ entendem que as instituições ligadas à política econômica já se encontram melhor estruturadas e consolidadas que as instituições políticas.

No geral, as opiniões quase se dividem ao meio em relação à necessidade de as instituições econômicas serem autônomas em relação às instituições políticas, sendo que essa proporção cai para 35\% na indústria e, inversamente, sobe para 77\% nas entidades do comércio e demais setores. Pouco mais de $70 \%$ do total entendem que as instituições econômicas devem ser autônomas em relação aos diversos grupos econômicos e sociais, inclusive os próprios empresários, sendo tal entendimento mais intenso nas entidades nacionais e nas entidades ligadas ao comércio. Apenas pouco mais da metade entendem que algumas instituições econômicas devem ser autônomas.

IV. A AVALIAÇÃO SOBRE O PESO POLÍTICO DOS GRUPOS SOCIAIS E DAS INSTITUIÇÕES POLÍTICAS

Quanto à importância dos grupos na política nacional, a avaliação dos presidentes, em porcentagem, divide-se da seguinte forma:

TABELA 2 - INFLUÊNCIA POLÍTICA DOS GRUPOS SOCIAIS

\begin{tabular}{|c|c|c|c|c|}
\hline GRUP OS & $\begin{array}{c}\text { MUTO } \\
\text { IMPORTANTE }\end{array}$ & IMPORTANTE & $\begin{array}{c}\text { POUCO } \\
\text { MMPORTANTE }\end{array}$ & SEM IMP ORTẤN NCIÁ \\
\hline Banqueiros & $23 \%$ & $44 \%$ & $25 \%$ & $8 \%$ \\
\hline Grandes industriais & $26 \%$ & $56 \%$ & $18 \%$ & $0 \%$ \\
\hline Grandes prop rietários rurais & $20 \%$ & $44 \%$ & $28 x$ & $8 \%$ \\
\hline Empresários estrangeiros & $3 \%$ & $41 \%$ & 41 z & 13 \% \\
\hline Grandes comerciantes & $26 \%$ & $46 \%$ & $28 x$ & $0 x$ \\
\hline Pequenos e médios empresários & $31 \%$ & $41 \%$ & $23 x$ & $5 \%$ \\
\hline Pequenos proprietários nurais & $23 \%$ & $26 \%$ & $43 x$ & $8 \%$ \\
\hline Atos funcionários dos órgâos estatais & $13 \%$ & $51 \%$ & $31 \%$ & $5 \%$ \\
\hline Senadores & $51 \%$ & $39 \%$ & $10 \%$ & $0 \%$ \\
\hline Deputados federais & $49 \%$ & $41 \%$ & $10 x$ & $0 \%$ \\
\hline Govemadores & $56 \%$ & $36 \%$ & $8 x$ & $0 \%$ \\
\hline Trabalhadores & $28 \%$ & $54 \%$ & $15 x$ & $3 \%$ \\
\hline Trabalh adores sem-terra & $5 \%$ & $39 \%$ & $23 x$ & $33 \%$ \\
\hline Miltares & $5 \%$ & $46 \%$ & $36 \%$ & $13 \%$ \\
\hline
\end{tabular}

rUNIE: o autor.

NOTA: Fizemos aproximações para totalizar 100\%. 
Em suma, entre os grupos aos quais se atribuem muita importância estão, por ordem decrescente, os governadores, os senadores, os deputados federais e, mais distantes, os pequenos e médios empresários e os trabalhadores. Se somarmos as indicações de muita e alguma importância, em ordem decrescente, os principais seriam os governadores, os deputados federais e os senadores, os grandes industriais, os trabalhadores e os grandes comerciantes. Dos que têm pouca ou nenhuma importância na opinião dos presidentes, destacam-se os trabalhadores sem-terra, os militares, os empresários estrangeiros e os pequenos proprietários rurais.

Quando a questão da importância é proposta a respeito das instituições políticas e de outros órgãos públicos, bancos e empresas multinacionais, a opinião dos presidentes divide-se da seguinte forma:

TABELA3 - IMPORTÂNCIA DAS INSTITUIÇÕES POLÍTICAS E DE OUTROS ÓRGÃOS

\begin{tabular}{|c|c|c|c|c|}
\hline INSTITUIÇČES & $\begin{array}{c}\text { MUITO } \\
\text { IMPORTANTE }\end{array}$ & IMPORTANTE & POUCO IMP ORTANTE & SEM IMPORTÂ NCIĂ \\
\hline Entidades empresariais & $33 \%$ & 56 \% & $10 \%$ & $0 \%$ \\
\hline Empresas multinacionais & $8 \%$ & $44 \%$ & $31 \%$ & $18 \%$ \\
\hline $\begin{array}{l}\text { Sindicatos de } \\
\text { trdalhadores }\end{array}$ & $26 \%$ & $61 \%$ & $10 \%$ & $3 \%$ \\
\hline breja Cáólica & $10 \%$ & $28 \%$ & $45 \%$ & $16 \%$ \\
\hline Forças Amadas & $5 \%$ & $38 \%$ & $44 \%$ & $13 \%$ \\
\hline Partidos políticos & $51 \%$ & $39 \%$ & $10 \%$ & $0 \%$ \\
\hline $\begin{array}{l}\text { Presidência da } \\
\text { República }\end{array}$ & $87 \%$ & $13 \%$ & $0 \%$ & $0 \%$ \\
\hline Congresso Nacional & $74 x$ & $23 \%$ & $3 \%$ & $0 \%$ \\
\hline Fundos de pensẫo & $8 \%$ & $31 \%$ & $44 \%$ & $18 \%$ \\
\hline FMle Baco Mundial & $5 \%$ & $41 \%$ & $41 \%$ & $13 \%$ \\
\hline
\end{tabular}

NOTAS:

1. FMI: Fundo Monetário Internacional.

2. Fizemos aproximações para totalizar $100 \%$.

As instituições que recebem maior atribuição de muito importante são a Presidência da República, o Congresso Nacional e os partidos políticos. Destoando dos demais tipos de entidade, cerca de $30 \%$ das entidades sindicais atribuem pouca importância ao Congresso Nacional. Quanto aos partidos políticos, enquanto nenhuma entre as entidades da indústria, ou associativa, ou do Sul ou nacional atribui pouca importância aos partidos, em torno de um quinto das entidades sindicais do comércio e as situadas no Sudeste assim o entendem. Se tomarmos as atribuições de pouca ou nenhuma importância, destacam-se os fundos de pensão, a Igreja Católica, as Forças Armadas, o FMI e o Banco Mundial.

\section{AAÇÃO DOS EMPRESÁRIOS FRENTE AOS PODERES CONSTITUÍDOS}

Sobre a relação entre as entidades e os poderes constituídos, quatorze dos presidentes (36\%) declararam que atuam mais intensamente junto ao poder Executivo estadual (Governador do Estado e secretarias), - sendo que mais de $80 \%$ entendem que os governadores têm obtido o devido apoio das assembléias legislativas, embora quase $90 \%$ avaliem que estas deveriam ser mais autônomas em relação ao Governador - contra quatro (10\%) que indicaram o poder Executivo federal (Presidente da República e ministros) e cinco (12\%) o Legislativo federal (Congresso Nacional). Se desagregarmos por setor, verificamos que dez das 15 entidades da indústria (66\%) declararam que atuam mais intensamente no Executivo estadual.

A respeito do grau de abertura dos poderes constituídos aos interesses das entidades, também 14 presidentes avaliam que é o poder Executivo estadual, contra cinco que indicaram o Executivo federal e cinco o poder Legislativo federal. Por fim, em relação ao grau de sucesso das ações das entidades, quinze presidentes avaliaram que também é o Executivo estadual, contra quatro que apontaram o poder Executivo federal e seis o Legislativo federal. Mas dois terços dos presiden- 
tes entendem que falta ao poder Executivo, nos três níveis, "competência administrativa".

Enfim, se tomarmos as opiniões dos presidentes a respeito dos poderes constituídos, nos três níveis, considerando as três variáveis (onde atua mais intensamente, o grau de abertura e o grau de sucesso das ações), podemos aferir aspectos importantes da forma como se dá a relação entre as entidades aqui contempladas e tais poderes e a sua avaliação em relação à responsividade de cada um deles ${ }^{13}$. Sobre isso, ver a Tabela 4 , a seguir.

TABELA 4 - RESPONSIVIDADE DOS PODERES CONSTITUÍDOS: NÚMERO DE ENTIDADES POR SETOR E GERAL

\begin{tabular}{|c|c|c|c|c|c|}
\hline PODER & & INDÚSTRIA & COMERCIO & OUTROS & GERAL \\
\hline \multirow{3}{*}{ Judiciário } & Alta & 3 & 4 & 0 & 7 \\
\hline & Média & 1 & 1 & 2 & 4 \\
\hline & Baxa & 1 & 2 & 2 & 5 \\
\hline \multirow{3}{*}{ Executivo municipal } & Alta & 6 & 6 & 4 & 16 \\
\hline & Média & 1 & 2 & 1 & 4 \\
\hline & Baixa & 2 & 0 & 0 & 2 \\
\hline \multirow{3}{*}{ Legislativo municipal } & Alta & 1 & 3 & 2 & 6 \\
\hline & Média & 0 & 0 & 2 & 2 \\
\hline & Baxa & 0 & 1 & 1 & 2 \\
\hline \multirow{3}{*}{ Executivo estadual } & Alta & 8 & 6 & 2 & 16 \\
\hline & Média & 3 & 3 & 2 & 8 \\
\hline & Baxa & 1 & 0 & 1 & 2 \\
\hline \multirow{3}{*}{ Legislativo estadual } & Alta & 2 & 5 & 3 & 10 \\
\hline & Média & 5 & 3 & 2 & 10 \\
\hline & Baxa & 1 & 1 & 2 & 4 \\
\hline \multirow{3}{*}{ Executivo federal } & Alta & 3 & 2 & 3 & 8 \\
\hline & Média & 3 & 2 & 3 & 8 \\
\hline & Baxa & 2 & 1 & 2 & 7 \\
\hline \multirow{3}{*}{ Legislativo federal } & Alta & 1 & 4 & 1 & 6 \\
\hline & Média & 6 & 1 & 5 & 12 \\
\hline & Baxa & 2 & 1 & 3 & 6 \\
\hline
\end{tabular}

Quando perguntados sobre qual deveria ser a sua própria ação diante das instituições democráticas brasileiras, pouco mais da metade dos presidentes entendem que as entidades empresariais deveriam agir no sentido de que, no âmbito federal, o poder Executivo tenha o apoio do Legislativo e quase $80 \%$ concordam que os empresários devem atuar no sentido de que o Legislativo tenha maior autonomia em relação ao Executivo. Nas entidades do sudeste é que se encontra a menor adesão: apenas metade a esse tipo de atuação. Mais de $90 \%$ do geral afirmam que a relação entre os poderes Executivo e Legislativo merece a preocupação do empresariado.

Ainda sobre a ação da entidade frente à relação entre os poderes Executivo e Legislativo, agora nos níveis estadual e municipal, apenas pouco mais de $45 \%$ entendem que as entidades empresariais devem atuar no sentido de que os governadores e os prefeitos tenham o apoio das assembléias legislativas e câmaras municipais, embora na indústria e nas entidades sindicais esse entendimento ultrapasse os $50 \%$. Dois terços concordam que as entidades empresariais devem atuar para que as casas legislativas sejam mais autônomas em relação aos poderes executivos. Da mesma forma, mais de $90 \%$ dos presidentes afirmam que a relação entre os poderes Executivo e Legislativo nos âmbitos estadual e municipal merece a preocupação do empresariado.

Quanto à ação voltada para a reforma política, há um consenso com relação à sua necessidade, embora apenas pouco mais da metade diga que sua

\footnotetext{
13 A expressão “responsividade” não está sendo aqui tomada em toda a complexidade que possui na teoria da democracia, mas apenas se refere à relação entre um dado grupo de indivíduos e a abertura, a permeabilidade e a receptividade de certas instituições políticas.
} 
entidade está atuando a respeito. Mais de $80 \%$ afirmam que pretendem atuar. Quase $90 \%$ entendem que o empresariado está preparado para atuar, mas somente pouco mais da metade avalia que a ação da própria entidade em tal reforma será decisiva para o futuro da democracia no Brasil. Mais de 80\% entendem que a melhor forma de atuar é por meio das próprias entidades empresariais e é a mesma proporção dos que se sentem bem informados sobre a reforma política. A maior parte dos presidentes avalia que não serão as entidades as mais beneficiadas por essa reforma. Veremos mais sobre a questão da reforma política no próximo item.

\section{A QUESTÃO DA REFORMA POLÍTICA}

Sobre as condições gerais da reforma política, as respostas dos presidentes podem ser sintetizadas na tabela abaixo ${ }^{14}$.

TABELA5-AVALIAÇÃO SOBREAREFORMA POLÍTICA

\begin{tabular}{|l|c|c|}
\hline AFIRMAÇÄ́ & COIICORD A FOR TEMEIITE & COIICORDA \\
\hline É necessária & $85 \%$ & $15 \%$ \\
Tem que ser rápida & $58 \%$ & $36 \%$ \\
Tem que ser ampla e protunda & $76 \%$ & $21 \%$ \\
As condiçốes sấo favoráveis & $26 \%$ & $60 \%$ \\
Deveria ter sido feita ainda no governo FHC & $54 \%$ & $41 \%$ \\
Tem que ocorrer no Congresso Nacional & $46 \%$ & $39 \%$ \\
\hline
\end{tabular}

FONTE: 0 autor.

NOTA: A alternativa apresentada foi o poder Judiciário, escolhido por somente $16 \%$.

Todos os entrevistados entendem que a reforma política é necessária mas, em outra pergunta, quase $20 \%$ responderam que se sentem pouco informados sobre o assunto. Quanto a outros as- pectos da reforma política e sua importância para o futuro da democracia no Brasil, a posição dos presidentes pode ser apresentada da seguinte forma:

\section{TABELA 6 - AVALIAÇÃO SOBRE ITENS DAREFORMA POLÍTICA}

\begin{tabular}{|c|c|c|c|c|}
\hline AFIRMAÇÃO & $\begin{array}{l}\text { CONCORDA } \\
\text { FORTEMENTE }\end{array}$ & CONCORDA & DISCORDA & $\begin{array}{l}\text { DISCORDA } \\
\text { FORTEMENTE }\end{array}$ \\
\hline A fidelidade partidária é imp rescin divel & $49 \%(19)$ & $33 \%(13)$ & $15 \%(6)$ & $\cdot$ \\
\hline $\begin{array}{l}\text { O financiamento público das campanhas eleitor ais } \\
\text { é imprescind'úel }\end{array}$ & $13 \%(5)$ & $46 \%(18)$ & $23 \%(9)$ & $10 \%(4)$ \\
\hline $\begin{array}{l}\text { O financiamento público enquanto única forma de } \\
\text { financiamento de campanhas }\end{array}$ & $13 \%(5)$ & $30 \%(12)$ & $41 \%(16)$ & $10 \%(4)$ \\
\hline A política nos âmbitos estadual e municip al deve & $56 \%(22)$ & $41 \%(16)$ & $3 \%(1)$ & $0 \%$ \\
\hline Voto de legenda com listas partidárias fechadas (*) & $3 \%(1)$ & $28 \%(11)$ & $26 \%(10)$ & $13 \%(5)$ \\
\hline $\begin{array}{l}\text { Feder açóes partidárias estáveis e duradour as } \\
\text { devern substituir as coligaçốes ( } \times \text { ) }\end{array}$ & $3 \%(1)$ & $54 \%(21)$ & $21 \%(8)$ & $5 \%(2)$ \\
\hline $\begin{array}{l}\text { Coincidência das eleiçốes em todos os níveis } \\
\text { A redução do número de partidos é fundamental }\end{array}$ & $\begin{array}{l}23 \%(9) \\
36 \%(14)\end{array}$ & $\begin{array}{l}33 \%(13) \\
44 \%(17)\end{array}$ & $\begin{array}{l}28 \%(11) \\
13 \%(5)\end{array}$ & $\begin{array}{c}10 \%(4) \\
0 \%\end{array}$ \\
\hline $\begin{array}{l}\text { Maior controle da sociedade sobre os grandes } \\
\text { partidos }\end{array}$ & $23 \%(9)$ & $54 \%(21)$ & $15 \%(6)$ & $5 \%(2)$ \\
\hline $\begin{array}{l}\text { Fim do voto obrigatório } \\
\text { Contr ole sobre as pesquis as de intenção de voto }\end{array}$ & $\begin{array}{l}28 \%(11) \\
20 \%(8)\end{array}$ & $\begin{array}{l}44 \%(17) \\
46 \%(18)\end{array}$ & $\begin{array}{l}21 \%(8) \\
20 \%(8)\end{array}$ & $\begin{array}{l}5 \%(2) \\
10 \%(4)\end{array}$ \\
\hline $\begin{array}{l}\text { A propaganda eleitor al deve ser regulada pela } \\
\text { reforma politica }\end{array}$ & $41 \%(16)$ & $51 \%(20)$ & $3 \%(1)$ & $3 \%(1)$ \\
\hline $\begin{array}{l}\text { O peso do poder econômico nas eleiçốes não é } \\
\text { uma questấo fundamental par a a reforma política }\end{array}$ & $3 \%(1)$ & $23 \%(9)$ & $62 \%(24)$ & $10 \%(4)$ \\
\hline $\begin{array}{l}\text { Osistema eleitor al deve ser alterado pela reforma } \\
\text { política }\end{array}$ & $56 \%(22)$ & $31 \%(12)$ & $13 \%(5)$ & $0 \%$ \\
\hline Q voto distrital é o mais adequado ( $\left.{ }^{\pi x \pi}\right)$ & $21 \%(8)$ & $46 \%(18)$ & $20 \%(8)$ & $0 \%$ \\
\hline
\end{tabular}

NOTAS:

1. (*) Mais de $30 \%$ dos entrevistados não sabem ou não responderam.

2. (**) Quase $18 \%$ não souberam responder.

3. $\left.{ }^{\star * \star}\right)$ Quase $15 \%$ não souberam responder.

14 Nas duas próximas tabelas, a não totalização de $100 \%$ nas linhas deve-se ou às aproximações, ou à discordância, ou à ausência de resposta ou à alegação de que não sabe. Quando a totalização é de $100 \%$, significa que não houve nenhum tipo de discordância. 
Quanto ao financiamento público de campanha como a única forma legal, a concordância é maior entre as entidades de outras regiões além do Sul e do Sudeste e tem pouca adesão entre as entidades nacionais. $\mathrm{O}$ fim do voto obrigatório, que é defendido por mais de dois terços dos entrevistados, é quase unânime nas entidades comerciais e nas entidades do Sudeste, enquanto no Sul está abaixo dos $60 \%$.

Mais de $90 \%$ dos presidentes esperam que a relação entre os poderes Executivo e Legislativo fique mais equilibrada com a reforma política e todos concordam, sendo que $80 \%$ fortemente, que tal reforma é fundamental para o crescimento e o desenvolvimento do país. Mas menos de $40 \%$ dos entrevistados entendem que a reforma política deve ser uma forma de alterar o papel do Estado na economia e o processo de formulação e implementação da política econômica. Dois terços dos entrevistados entendem que a sociedade em geral seria a mais beneficiada com a reforma política.

Por fim, outros assuntos que, segundo os entrevistados, deveriam constar da reforma política estão: aperfeiçoamento da legislação e dos mecanismos de fiscalização e julgamento da Justiça Eleitoral; formas de controle sobre o poder Executivo; formas mais intensas de accountability ${ }^{15}$; fidelidade aos programas partidários e às propostas de campanha; voto distrital misto etc. Foram mencionados também outros assuntos que não são propriamente parte uma reforma dessa natureza, como as relações trabalhistas, a previdência social, administração pública e o combate à corrupção.

\section{CONSIDERAÇÕES FINAIS}

Em primeiro lugar, é necessário reafirmar que as inferências e generalizações só podem ser feitas com certa segurança estritamente para as entidades consideradas neste trabalho. Entretanto, como dissemos acima, nosso objetivo não é a generalização, mas sim retirar elementos importantes para outros estudos sobre a representação política empresarial e a relação entre o empresariado organizado, a democracia e o funcionamento das instituições democráticas ${ }^{16}$.

\footnotetext{
15 Expressão usada pelo respondente.

16 Apenas a título de exemplo, por meio do questionário, também consultamos os presidentes das entidades acerca daqueles que seriam os nomes mais representativos do
}

Em relação ao rendimento analítico da mobilização de variáveis relacionadas às concepções, opiniões e avaliações, entendemos que isso nos permite obter informações sobre um dos elementos importantes para o momento da ação, ou da sua falta, frente às questões concretas, dado que se trata, no caso, do julgamento a respeito das instituições políticas e dos seus valores subjacentes. Essas informações indicam-nos as tendências de aceitação, apoio, recusa ou contraposição por parte dos empresários em relação a certas características importantes do regime democrático vigente no Brasil, fornecendo hipóteses de trabalho melhor fundamentadas e sugerindo os prováveis âmbitos e padrões nos quais se dariam as ações concretas do empresariado, bem como as possíveis contradições ou mudanças de posição.

As inconsistências das respostas não devem ser relevadas, mas há que se considerar que isso se deve ao fato de que se trata de idéias e não de ações. Enfim, faz parte deste tipo de pesquisa, voltada para as concepções e avaliações, tratar com certa confusão por parte dos agentes o que se entende que é e o que se deseja e o que se espera. As opiniões podem mudar, o que é normal, em especial no regime democrático, independentemente da existência de uma crise política, como a que o país enfrentou recentemente. Isso reforça a importância da continuidade deste estudo para o âmbito das ações concretas do empresariado frente à democracia e às suas instituições políticas.

Sobre isso, cabem algumas outras observações importantes. Neste trabalho mobilizamos variáveis que geralmente não ocupam posição central nos estudos sobre o empresariado, ou seja, as posições e os comportamentos do empresariado frente às instituições e questões mais estritamente políticas. Quando tomamos por referência trabalhos como os de Maria Antonieta Leopoldi (2000), Eli Diniz e Renato Boschi (2004) e Wagner Pralon Mancuso (2004), observamos algumas diferen-

empresariado nacional, e os três mais mencionados foram, em ordem decrescente de referência, Jorge Gerdau Johannpeter, Armando Monteiro Neto e Antônio Ermírio de Moraes. Em pesquisas posteriores, pretendemos avaliar qualitativamente os fundamentos das respostas e desenvolver mais intensamente a questão da ação política concreta desse grupo social frente aos processos relacionados ao funcionamento das instituições democráticas. 
ças em relação aos resultados aqui obtidos. Diniz e Boschi (2004), por exemplo, mesmo quando consideram os valores e as percepções desse grupo social, fazem-no em relação aos efeitos das reformas liberalizantes, as perspectivas do desenvolvimento econômico e os aspectos organizacionais das entidades, enquanto procuramos mobilizar variáveis voltadas para outro aspecto da política e do Estado, ou seja, a questão do funcionamento das instituições democráticas. Se as transformações ocorridas a partir do início dos anos 1990 no campo econômico são bastante relevantes, elas não o foram menos no campo políticoinstitucional, exigindo que se trabalhe com outras mudanças importantes ao longo desse período.

O interesse nesta abordagem alternativa da ação política do empresariado está nos seguintes aspectos: 1) permite trabalhar questões mais próximas ao grupo ou classe social e não apenas de suas instituições de representação, exatamente por tratar da questão da representação política, dimensão fundamental na análise da ação coletiva; 2) considera as implicações da relação entre esse importante grupo social e o funcionamento e as características do processo, ainda em andamento, de construção da democracia no Brasil; 3) permite comparações com a relação que a população em geral e outros grupos sociais em particular têm com as instituições democráticas; 4) considera com maior intensidade o fato de que mesmo espaços mais insulados do processo decisório no âmbito do Estado estão mais sujeitos às pressões dos diversos grupos sociais, entre eles e, em especial, o empresariado, em um contexto democrático. Daí a importância de analisar-se a relação entre os grupos sociais e as instituições quando estas são sendo estudadas; 5) o foco de análise do empresariado centrado na política econômica tende a concentrar-se na relação entre esse grupo e o âmbito federal do processo decisório, em especial o poder Executivo, deixando de lado outros espaços importantes da ação política do empresariado e, principalmente, do próprio Estado e do governo, como os governos estaduais, as assembléias legislativas e as prefeituras ${ }^{17}$; 6) a análise frente à questão das instituições políticas per-

17 Vimos acima a importância que o poder Executivo estadual assume no dia-a-dia da ação política da maior parte das entidades aqui analisadas. Voltaremos a essa questão mais adiante. mite problematizar sob outra ótica aspectos da adesão tanto à democracia, quanto à "ideologia liberal stricto sensu" (idem, p. 32) e 7), ou seja, se o empresariado é ou deixa de ser liberal também em relação aos fundamentos da democracia. Além disso, a vantagem de pesquisar outros setores além do industrial também permite maior alcance da análise, no sentido de aferir as homogeneidades e heterogeneidades no conjunto do empresariado.

Quanto ao rendimento das agregações feitas com os dados obtidos, servem mais para estabelecer especulações futuras e não se contrapõem à tese da homogeneidade e da coesão das opiniões, a despeito da diversidade de entidades; mas isso também não significa consenso em relação a tudo o que se refere ao funcionamento da nossa democracia. As desagregações mostram alguns aspectos interessantes do conjunto do empresariado brasileiro, cuja pertinência e principalmente os motivos subjacentes devem ser considerados em estudos futuros: 1) as entidades de outras regiões que não Sul e Sudeste estão menos convencidas em relação à consolidação da democracia; 2) as entidades associativas estão menos convencidas da importância da presença dos empresários na política para o sucesso da democracia e confiam menos nos poderes Executivo e Legislativo federais; 3 ) as entidades nacionais defendem com maior intensidade uma interferência maior do Congresso Nacional na política econômica; 4) ainda que, na média, metade dos entrevistados entendam que a reeleição para cargos do poder Executivo tenha sido favorável à nossa democracia, as entidades da indústria (64\%) e mais ainda aquelas do Sudeste (83\%) mostram-se muito mais favoráveis a este aspecto do sistema político brasileiro; 5) as entidades do sul e do sudeste estão mais convencidas, em comparação com a média geral, em relação à prioridade do bom funcionamento das instituições políticas frente às econômicas, mas a maior parte das entidades do comércio e dos serviços pensam o contrário; 6) as entidades do comércio (77\%) também tendem a defender maior autonomia da política econômica frente às instituições políticas do que as industriais (35\%), o mesmo ocorrendo a respeito da relação entre política econômica e os diversos grupos sociais e 7) quase todas entidades do comércio defendem o fim do voto obrigatório. Podemos dizer que, entre os entrevistados, as entidades ligadas ao comércio tendem a assumir uma postura mais próxima do ideário liberal no que diz respeito à rela- 
ção entre Estado, sociedade e mercado.

Enfim, nossa pesquisa não permite especular sobre as razões desses indicadores, mas indicam a necessidade de confirmá-los, explorá-los e verificar por que isso ocorre e suas possíveis conseqüências sobre o regime político.

Quando comparamos a relação entre os empresários aqui contemplados e as análises sobre o comportamento do empresariado frente à democracia em outros países, em especial no contexto da ascensão de forças políticas consideradas de esquerda, constatamos que essa adesão não está apenas relacionada com a economia, mas também com as instituições políticas democráticas (BRESSER-PEREIRA, 2006; WAISSBLUTH \& LARA, 2006). Isso não é surpreendente, dado que, de um lado, os empresários tendem naturalmente a preocupar-se mais com a economia e a política econômica, e de outro lado, que os governos que poderiam ser chamados de centro-esquerda ou simplesmente de esquerda, com poucas exceções, não se preocuparam intensamente com a questão do aperfeiçoamento das instituições políticas democráticas. Entretanto, essas análises também não consideram em profundidade a relação entre empresários e funcionamento da democracia, mas sim a questão da política econômica.

A questão da relação com a esquerda é importante não só pela chegada do maior partido desse campo do espectro político à Presidência da República no Brasil em 2002, mas também pelo que se observa em relação à mudança do discurso e da prática do empresariado frente aos setores aos quais geralmente ele próprio atribui tal postura. Se nos anos 1980 e até início dos 1990 verificava-se uma atitude reticente e preconceituosa em relação às forças políticas de esquerda por parte do empresariado organizado, já em meados dos anos 1990 as mudanças que ocorriam nos partidos de esquerda em relação às suas propostas para o país também se refletiam e eram percebidas pelos empresários e, certamente, continuarão a ser importantes no processo de chegada ao governo, como também na amplitude e no conteúdo das reformas que podem ser feitas na sociedade e no Estado brasileiros (COSTA, 2003; 2005a; 2005b) ${ }^{18}$.

18 Convém ressaltar que em outros trabalhos consideramos apenas a Associação Comercial de São Paulo e a Federação do Comércio do Estado de São Paulo na década de 1990 (cf. COSTA 2003; 2005a; 2005b).
Seja como for, alguns comentários podem ser feitos a partir dos resultados de nossa pesquisa. Considerando certos indicadores do que poderia ser associado à posição de esquerda, observamos os seguintes aspectos a respeito das opiniões dos entrevistados: 1) em relação à questão da participação política, quase $85 \%$ entendem que a grande vantagem da democracia é a possibilidade de participação do maior número de pessoas nas decisões e $76 \%$ discordam da idéia de que o problema da democracia seriam os excessos de participação que ela gera; 2) quanto à tensão entre justiça social e manutenção da ordem, $77 \%$ avaliam que a desigualdade econômica é uma ameaça à democracia, contra apenas $18 \%$ que aceitam o fim do regime democrático diante da ameaça à propriedade privada e só $10 \%$ que aceitariam isso diante da ameaça aos valores morais e religiosos da sociedade; por fim, como já afirmado acima, mais de dois terços discordam de que o bom funcionamento das instituições responsáveis pela elaboração da política econômica - ou seja, os ministérios da área econômica e as agências responsáveis pela implementação das medidas relacionadas ao funcionamento da economia - é mais importante do que o bom funcionamento do Congresso Nacional e dos partidos políticos e 3) quanto à relação entre Estado e mercado, apenas 38\% entendem que a reforma política deve ser uma forma de alterar o papel do Estado na economia. Enfim, os dados reforçam a tendência já observada nos anos 1990 de aproximação entre setores do empresariado e forças políticas classificadas como de esquerda (COSTA, 2005a; 2005b).

A comparação com os resultados de nossos estudos anteriores sobre o empresariado também pode ser interessante. Por um lado, percebemos que as idéias expressas pelas entidades aqui contempladas têm sido convergentes e favoráveis ao quadro geral das instituições em funcionamento, mesmo que haja críticas difusas e, por outro lado, podemos discutir algumas hipóteses frente ao conjunto de idéias relativas à democracia e às instituições do regime democrático por parte do empresariado brasileiro.

Entre essas hipóteses, algumas foram corroboradas, mas outras não. Entre as primeiras estão: 1) a adesão ao regime democrático; 2) um certo ceticismo em relação à consolidação e à viabilidade da democracia no Brasil, sendo que, como vimos, nas entidades situadas fora das re- 
giões Sul e Sudeste tal receio é ainda maior; 3) o reconhecimento dos limites do alcance da sua própria ação política frente às questões politicoinstitucionais; 4) a idéia de que é possível fazer política sem assumir uma posição partidária; 5) o entendimento de que um dos maiores problemas do poder Executivo, nos três níveis, é a falta de competência administrativa e 6) a avaliação de que o problema da coisa pública é a falta de competência administrativa.

Entre as hipóteses não confirmadas estão: 1) não há uma postura contrária aos partidos políticos, apesar da permanência da busca de uma postura política "apartidária”; 2) não há uma crítica ao poder Legislativo enquanto instituição, nem a aceitação do predomínio do poder Executivo sobre o Legislativo; 3) a ação dos lobbies é reconhecida como constitutiva e favorável à democracia; 4) não se atribui às características das instituições políticas a causa dos problemas de nossa democracia; 5) o entendimento de que o bom funcionamento das instituições relacionadas à política econômica é menos importante do que das instituições políticas democráticas; 6) não houve o predomínio da idéia de que as instituições econômicas devem ser autônomas em relação às instituições políticas; 7) atribuiu-se baixa relevância a atores políticos como os militares, a Igreja Católica, os empresários estrangeiros, o FMI e o Banco Mundial; 8) não há oposição às formas participativas de funcionamento da democracia e 9) dentre todos os poderes e níveis, as entidades atuam mais intensamente junto ao poder Executivo estadual, que também é considerado o mais aberto e em que as entidades declaram ser mais bem-atendidas as suas demandas.

Ainda que entre os respondentes predominem presidentes de entidades estaduais (federações e associações de âmbito estadual), isso não explica porque se dá maior atenção e, principalmente, avalia-se melhor o governo estadual, considerando a importância da política federal sobre o funcionamento da economia. O que parece é que, mesmo quando têm uma atuação mais nacional, as entidades não podem prescindir de uma presença importante na política estadual, em especial no âmbito do poder Executivo. Enfim, isso implica a necessidade de aprofundar-se as questões que trabalhamos aqui.

Ainda sobre esse aspecto, podemos fazer algumas comparações interessantes com o traba- lho de Eli Diniz e Renato Boschi (2004, p. 196), que chamaram a atenção para a "centralidade" do poder Legislativo nos padrões de ação política das entidades empresariais industriais. Observamos que a ação da maior parte das entidades, em especial as da indústria, concentra-se não no poder Executivo ou no Legislativo federais, mas sim no poder Executivo estadual. Enfim, isso sugere que, apesar de termos contemplado um maior número de entidades de abrangência estadual e da centralidade do Executivo federal na definição da política econômica, o dia-a-dia das entidades está mais voltado para as questões que se colocam no âmbito do estado e, portanto, têm como foco principal de atuação o Governador de Estado e as Secretarias estaduais.

Embora transcenda os objetivos mais imediatos deste trabalho, convém destacar outro aspecto interessante. De uma forma geral, fica evidente que há uma adesão dos presidentes das entidades aqui contempladas à democracia em termos gerais, mesmo que a forma como isso se dê não seja algo que Eli Diniz e Renato Boschi chamem de "uma postura favorável à democracia como aspecto de um ideário liberal mais estruturado" (idem, p. 32). Como foi sugerido acima, há uma adesão dos entrevistados aos pressupostos e fundamentos da democracia liberal, mostrando que, nesse sentido, eles são liberais $^{19}$. Além disso, constatamos que, como afirmam Eli Diniz e Renato Boschi, uma mudança no rumo da política econômica teria impacto na relação entre empresariado e democracia. Entretanto, a pesquisa sugere que tal impacto poderia ocorrer, mas não necessariamente no sentido da determinação das mudanças na economia sobre a relação entre empresários e democracia, mas sim pelo fato de que essas mudanças poderiam exigir uma outra posição do empresariado frente às instituições políticas, de modo a alterar as bases institucionais do processo de definição da política econômica, como, por exemplo, a relação entre os poderes Executivo e Legislativo e o insulamento burocrático.

Um outro elemento importante para esta discussão é a análise das formas de ação concreta

19 A adesão dos empresários aqui contemplados à democracia é maior, por exemplo, do que aquela aferida pelo Estudo Eleitoral Brasileiro (ESEB) e pela Organização das Nações Unidas (ONU) para a população em geral em 2002 (cf. PAIVA, SOUZA \& LOPES, 2004). 
das entidades empresariais. Nossa pesquisa mostrou que os presidentes entendem que devem agir para que o poder Legislativo, em especial no nível federal, apóie, mas que também seja autônomo, em relação ao Executivo, e que a relação entre esses poderes, nos três níveis, é de grande relevância para os empresários. Igualmente há uma forte indicação de que as entidades sentem-se dispostas, preparadas e bem-informadas para atuar em um processo de reforma política, embora não vejam as instituições políticas como um dos principais problemas da democracia brasileira ${ }^{20}$. Ainda que no âmbito das declarações, são posturas favoráveis à consolidação dos indicadores liberais clássicos de democracia: responsividade, equilíbrio entre os poderes, fortalecimento das instituições representativas, postura favorável à participação etc.

Enfim, fazem parte do processo decisório e do regime político - democráticos, no caso - tanto as instituições claramente políticas, eletivas e mais responsivas, quanto também aquelas burocráticas e insuladas. Tanto ou mais relevante que as adaptações e as transformações ocorridas no aspecto organizacional interno às entidades são as mudanças em relação à adesão e ao comportamento destas frente à democracia e a suas instituições. Portanto, observamos que há uma posição do empresariado favorável ao "ideário liberal”, ao menos e talvez mais intensamente no que diz respeito às instituições políticas liberal-democráticas, o que reforça a importância destas como variáveis de análise do empresariado em jovens democracias como a brasileira.

Outros estudos sobre o empresariado atribuem grande importância política a esse grupo em relação aos últimos governos federais, mas não analisam a relação entre essa classe e as instituições políticas, nem aprofundam a caracterização dos padrões de sua ação política e de sua interferência no processo decisório. Em sua análise de relação entre a burguesia e o governo Lula, Armando Boito Jr. faz apenas uma referência genérica à ocupação dos postos-chave da política eco-

20 Essa posição pode ser alterada caso alguns movimentos, como o da Federação das Indústrias do Estado do Paraná (FIEP), voltados para discussão sobre o sistema político e a reforma política, ganhem maior fôlego e continuidade. Sobre essa iniciativa da FIEP, cf. Rede de Participação Política do Empresariado (s/d). nômica, sem um detalhamento mais preciso das formas de ação da "grande burguesia interna industrial e agrária” ou da fração hegemônica do capital financeiro, o que poderia levar a uma correlação imediata entre poder econômico e poder político dessas frações. A nossa pesquisa indica aspectos das concepções e dos padrões de ação de frações que o autor talvez considerasse como "não-hegemônicas do bloco no poder", dado que entre as entidades aqui contempladas predominam aquelas ligadas ao médio e ao pequeno capital. Boito Jr. (2006) defende que há uma identificação das entidades do grande capital financeiro com os recentes governos. Mas nossos dados sugerem que essa não é a percepção predominante entre os entrevistados, pois os grandes industriais, seguidos dos grandes comerciantes e dos pequenos e médios empresários, são considerados mais importantes que os banqueiros e pouco mais da metade dos presidentes das entidades atribuem importância política às multinacionais - sendo que apenas 8\% atribuem muita importância -, e menos da metade fazem-no em relação ao FMI e ao Banco Mundial, aos quais somente 5\% atribuem muita importância.

Isso reforça a necessidade que nossa pesquisa indica de uma averiguação mais aprofundada das posições dos diversos subgrupos do empresariado, no sentido de maior fundamentação das inferências a respeito de seus interesses e do jogo de forças no interior desse grupo social; além disso, é necessário verificar se a percepção que os empresários possuem a respeito de suas condições e relação com o poder corresponde à realidade.

Considerando outro estudo, entre outros, que trata da relação entre empresariado e regime político democrático (LAMOUNIER \& SOUZA, 2002) $)^{21}$, observamos que a grande maioria dos entrevistados também defendia a redução do nú-

21 Trata-se de pesquisa realizada pelo Instituto de Estudos Econômicos, Sociais e Políticos de São Paulo (Idesp), intitulada A elite brasileira e a modernização do setor público, realizada entre agosto e outubro de 2002 com 450 pessoas influentes, entre eles grandes empresários, representantes de pequenos e médios empresários, dirigentes sindicais e parlamentares. Limitar-nos-emos a comentar os resultados dessa pesquisa que se referirem aos grandes, pequenos e médios empresários. Como foi dito acima, nossa pesquisa não pretende fazer uma representação do conjunto do empresariado e, portanto, as comparações serão feitas a partir dos objetivos específicos deste trabalho. 
mero de partidos, no caso, àqueles que possuíssem até 5\% de representação da votação nacional. Em média, o resultado também é o mesmo em relação ao financiamento público de campanha e à fidelidade partidária e não diverge muito em relação ao fim do voto obrigatório e ao voto distrital misto.

Quando comparamos os resultados aqui obtidos com os de outras pesquisas que contemplam aspectos semelhantes, podemos fazer comentários adicionais. Em relação à pesquisa feita em 2002 pelo Grupo de Opinião Pública da Universidade de Lima, no Peru, observamos que, dos entrevistados, mais de $90 \%$ não confiavam no poder Legislativo federal e mais de $95 \%$ não confiavam nos partidos políticos (GRUPO DE OPINIÃO PÚBLICA, 2003)22. Como mencionamos acima, nossa pesquisa indica índices muito mais favoráveis aos poderes constituídos e às instituições representativas brasileiros, como os partidos políticos, apesar de certa desconfiança em relação aos políticos profissionais ${ }^{23}$.

Em outra pesquisa, feita pela empresa Pricewaterhouse \& Coopers ${ }^{24}$, destaca-se fato de que, embora os líderes empresariais apontem para a necessidade de, entre outros fatores, políticas que favoreçam os negócios, a pesquisa não atribui nenhuma importância ao processo políticoinstitucional. A preocupação central é com o processo de globalização e as condições macro-econômicas favoráveis à atração e ao fomento de investimentos estrangeiros. Em relação a esses as-

22 Essa pesquisa contemplou os líderes empresariais peruanos, entrevistando 170 presidentes de diretórios das empresas de maior faturamento entre as 10 mil maiores empresas do Peru (GRUPO DE OPINIÃO PÚBLICA, 2003)

23 Podemos ressaltar que, assim como neste trabalho, a pesquisa feita no Peru também não pode pretender servir de uma amostra representativa do empresariado como um todo, visto não contemplar as “micro” e médias empresas.

24 Foram entrevistados 79 líderes empresariais, denominados CEOs, dos quais 26\% pertencem a empresas que faturam entre US\$ 100 milhões e 250 milhões anuais; $11 \%$ entre US\$ 251 milhões e US\$ 500 milhões; 3,8\% entre US\$ 501 milhões e US\$ 999 milhões; 21\% entre US\$ 1 bilhão e US $\$ 10$ bilhões e 5,1\% faturam acima de US\$10 bilhões. Por setor: 64\% são da indústria, 20,3\% são de instituições financeiras e $15,7 \%$, de instituições de tecnologia, comunicação, meios de comunicação e entretenimento (PRICE WATERHOUSE \& COOPERS, 2006). pectos, os problemas apontados são corrupção, pobreza, educação e segurança. Enfim, uma quase total desconsideração da política e das instituições políticas ${ }^{25}$. Em suma, tanto pelo teor do questionário que foi aplicado quanto pelas respostas apresentadas pelos "CEOs" "“Chief Executive Officers") que a Pricewaterhouse \& Coopers considera líderes empresariais, observa-se um grau maior de politização por parte dos presidentes de entidades que aqui foram entrevistados. Enquanto os CEOs estão mais preocupados com a corrupção, a estabilidade das políticas macro-econômicas e com a geopolítica, sendo a questão do Estado apenas tratada como "setor público", os presidentes das entidades aqui consideradas tendem a colocar-se mais ativamente diante das questões relacionadas ao funcionamento das instituições políticas, nas quais se dão os processos decisórios.

Por fim, na pesquisa sobre reforma política feita pelo Núcleo de Assuntos Estratégicos (NAE), ligado à Presidência da República (BRASIL. PRESIDÊNCIA DA REPÚBLICA. NAE, 2005) - que também não é representativa da totalidade da população brasileira ${ }^{26}$ - as questões mais importantes levantadas foram: a relação entre os poderes Executivo e Legislativo; os mecanismos de representação; a participação e o controle da sociedade sobre os partidos e os atores políticos; o financiamento das campanhas eleitorais e a "cultura cívica”. Os resultados obtidos pelo NAE são convergentes com os de nossa pesquisa. Vimos acima como a confiança nas instituições e a crença na importância dos espaços propriamente políticos na definição das políticas de Estado, mesmo a política econômica, sugerem uma postura favorável ao fortalecimento das instituições democráticas. Mais uma vez, a comprovação dessa confi-

25 Destoando um pouco do conteúdo das questões e das respostas, em entrevista anexa à pesquisa da Pricewaterhouse \& Coopers, Eugênio Staub afirmou a necessidade de uma reforma política radical para resolver o problema da corrupção, que seria um dos fatores mais graves em relação aos investimentos no Brasil.

26 Essa pesquisa, coordenada por professores da Universidade de São Paulo (USP) e do Instituto Universitário de Pesquisas do Rio de Janeiro (Iuperj), foi realizada junto a 50 mil brasileiros pertencentes aos setores público, empresarial, acadêmico, de meios de comunicação, classista, artístico, religioso e organizações não-governamentais (BRASIL. PRESIDÊNCIA DA REPÚBLICA. NAE, 2005). 
ança apenas poderia ser completamente aferida na análise da ação política concreta. Há convergência também em relação às expectativas face à oportunidade e à importância ou centralidade frente a outros problemas, e aos benefícios para a sociedade de uma reforma política, apesar da crença de que há pouca possibilidade de que tal reforma venha a ocorrer no curto prazo (idem, p. 51ss.).

Em relação à questão da reforma política: ainda que todos concordem com a sua necessidade e que as condições atuais são-lhe favoráveis, observa-se que a convicção é mais forte quando se considera que tal reforma já deveria ter sido feita no governo Fernando Henrique Cardoso. Ainda que esses dados não permitam nenhuma conclusão definitiva sobre a ação política das entidades aqui consideradas, observa-se que, tomando como referência o projeto de reforma política proposta pelas frentes que estão tratando desse assunto no Congresso Nacional, os presidentes das entidades empresariais concordam com o financiamento público das campanhas, mas não como única forma de financiamento.

Das outras propostas discutidas no Congresso Nacional, o fim do voto de legenda divide dois terços dos empresários consultados, sendo que o outro terço não soube responder. Quanto ao fim das coligações e a instalação de federações partidárias, há a concordância de mais de $60 \%$, mas muitos (mais de 20\%) não souberam responder. Como vimos acima, outras questões indicadas pelos entrevistados não estão sendo contempladas pela discussão parlamentar sobre a reforma política. Todavia, há uma certa convicção de que a reforma política poderá favorecer a sociedade, além de uma certa esperança de que a reforma equilibre a relação entre os poderes Executivo e Legislativo; a grande maioria dos respondentes acredita que essa reforma é fundamental para o desenvolvimento econômico do país, mesmo sem implicar alterações do papel do Estado na economia e na política econômica.

Dentro dos limites desta pesquisa, podemos fazer um exercício de pensar qual seria a agenda do empresariado em um processo de reforma política, a qual seria testada, de um lado, em relação a uma amostra mais representativa, e de outro lado, na análise de sua eventual ação política em relação a essa questão. Tal agenda teria como principais motivos: o combate à corrupção; um equilíbrio maior entre os poderes Executivo e
Legislativo, inclusive nos estados e maior municípios, embora sem implicar uma interferência demasiada do Congresso Nacional na política econômica; aumentar a confiabilidade das instituições; controle externo do poder Judiciário; reformulação do funcionamento das instituições políticas nos âmbitos estadual e municipal; fortalecimento dos partidos políticos e o melhoramento da competência administrativa da coisa pública. Quanto às medidas concretas que poderiam ser defendidas, seriam: fidelidade partidária; financiamento público de campanha; redução do número de partidos; fim do voto obrigatório; voto distrital; maior controle sobre as pesquisas de intenção de voto; maior controle sobre o uso do poder econômico e fim do voto obrigatório ${ }^{27}$.

Não sugerimos que esta é ou poderia ser a agenda que concretamente os empresários contemplados pela pesquisa defenderiam ou defenderão, dado que isso só pode ser comprovado no processo de análise das ações concretas. Sugerimos, sim, algumas hipóteses de trabalho e até mesmo as áreas que poderiam ser de maior ou menor resistência, ou que obteriam maior ou menor apoio, por parte da elite política do empresariado.

Em suma, os resultados da pesquisa indicam uma tendência a uma postura não só extremamente favorável à democracia como também um interesse maior pelas questões relacionadas ao funcionamento do regime político. Isso é bastante relevante, dada a importância que tem, e que pode vir a assumir, o empresariado organizado na sociedade e na política nacionais, seja pela sua presença, seja pela sua ausência. Mais uma vez, somente a análise da ação concreta permitirá testar as inferências parciais aqui levantadas e complementar o estudo aqui iniciado.

A análise da ação das entidades empresariais e de outras elites do empresariado permitir-nos-á testar outras hipóteses, tais como: 1) a falta de uma ação efetiva e agressiva no que tange à consolidação e à construção das instituições democráticas, em especial um processo de reforma política, amplo ou restrito; 2) a apatia frente ao

27 É interessante notar que, embora mais de $80 \%$ dos entrevistados tenham afirmado que suas entidades pretendem atuar em um eventual processo de reforma política, menos da metade avalia que tal participação terá um papel decisivo. 
desequilíbrio, fortemente criticado pelos presidentes das entidades aqui consideradas, entre os poderes Executivo e Legislativo, em todos os níveis, e 3) a contradição entre a declaração de preocupação em relação às instituições democráticas e a dificuldade de estabelecer ações que ultrapassem a defesa dos interesses econômicos dos seus filiados.
Entendemos que isso reforça a importância de chamar-se a atenção dos estudiosos tanto sobre o empresariado quanto sobre a democracia no Brasil para a relação entre os grupos sociais e as instituições políticas como forma de aprofundar a compreensão sobre as particularidades e as perspectivas da democracia no Brasil.

Paulo Roberto Neves Costa (paulocosta@ufpr.br) é Doutor em Ciências Sociais pela Universidade Estadual de Campinas (Unicamp), Professor de Ciência Política na Universidade Federal do Paraná (UFPR), coordenador do Núcleo de Pesquisa em Sociologia Política Brasileira da mesma instituição e Editor-Chefe da Revista de Sociologia e Política.

\section{REFERÊNCIAS BIBLIOGRÁFICAS}

ALMOND, G. \& VERBA, S. 1989. The Civic Culture. Political Attitudes and Democracy in Five Nations. London : Sage.

BOITO JÚNIOR, A. 2005. A burguesia no governo Lula. Crítica Marxista, Campinas, n. 21, p. 52-76, nov.

BRESSER-PEREIRA, L. C. 2006. Esquerda nacional e empresários na América Latina. Nueva Sociedad, Buenos Aires, n. 202, p. 121-132, mar.-abr. Disponível em : http:// www.bresserpereira.org.br/papers/2005/ 05.19 . Es querda \& E m presarios NuevaSociedad.pdf. Acesso em : 30.abr.2007.

COSTA, P. R. N. 2003. Empresariado e democracia no Brasil : 1984-1994. Campinas. Tese (Doutorado em Ciências Sociais). Universidade Estadual de Campinas.

2005a. Empresariado, regime político e democracia : Brasil, anos de 1990. Revista Brasileira de Ciências Sociais, São Paulo, v. 20, n. 57, p. 109-126, fev. Disponível em : http:// www.scielo.br/pdf/rbcsoc/v20n57/ a07v2057.pdf. Acesso em : 30.abr.2007.

2005b. Como os empresários pensam a política e a democracia : Brasil, anos 1990. Opinião Pública, Campinas, v. XI, n. 2, p. 422-449, out. Disponível em : http:// www.scielo.br/pdf/op/v11n2/26421.pdf. Acesso em : 30.abr.2007.

DINIZ, E. \& BOSCHI, R. R. 2004. Empresários, interesses e mercado : dilemas do desenvolvimento no Brasil. Belo Horizonte : UFMG.
GRUPO DE OPINIÃO PÚBLICA. 2003. Situación económica y empresarial del Perú. Barómetro Empresarial, V Encuesta Anual a Líderes Empresariales, jul.-ago. Lima : Universidad de Lima.

INGLEHART, R. 1988. The Renaissance of Political Culture. American Political Science Review, Washington, D. C., v. 82, n. 4, p. 12031230, Dec.

LAMOUNIER, B. \& SOUZA, A. 2002. As elites brasileiras e o desenvolvimento nacional : fatores de consenso e dissenso. Relatório de Pesquisa. São Paulo : Instituto de Estudos Econômicos, Sociais e Políticos de São Paulo.

LEOPOLDI, M. A. P. 2000. Política e interesses na industrialização brasileira : as associações industriais, a política econômica e o Estado. Rio de Janeiro : Paz e Terra.

MANCUSO, W. P. 2004. O lobby da indústria no Congresso Nacional : empresariado e política no Brasil contemporâneo. Dados, Rio de Janeiro, v. 47, n. 3, p. 505-547, out. Disponível em : http://www.scielo.br/pdf/dados/v47n3/ a03v47n3.pdf. Acesso em : 30.abr.2007.

PAIVA, D.; SOUZA, M. R. \& LOPES, G. F. 2004. As percepções sobre democracia, cidadania e direitos. Opinião Pública, Campinas, v. X, n. 2, p. 368-376, out. Disponível em : http://www.scielo.br/pdf/op/v10n2/22022.pdf. Acesso em : 30.abr.2007.

PRICE WATERHOUSE \& COOPERS. 2006. $2^{a}$ pesquisa de líderes empresariais brasileiros. 
Globalização e gestão de complexidades. São Paulo : Price Waterhouse \& Coopers. Disponível em : endereço http://www.pwc.com/images/ bz/Pesq_Lid_Emp_Bra.pdf. Acesso em : 3.jun.2006.
WAISSBLUTH, M. \& LARA, J. I. 2006. ¿Pueden la empresa y la izquierda convivir y no morir en el intento? Nueva Sociedad, Buenos Aires, n. 202, p. 98-111, mar.-abr. Disponível em : http://www.nuso.org/upload/articulos/ 3340_1.pdf. Acesso em : 30.abr.2007.

\section{OUTRAS FONTES}

BRASIL. PRESIDÊNCIA DA REPÚBLICA. NAE. 2005. Dimensão institucional. Contribuição para o tema reforma política. Cadernos NAE n. 5. Brasília : Presidência da República. Núcleo de Assuntos Estratégicos. Disponível em : http://www.iea.usp.br/iea/tematicas/futuro/pro- jeto/naereformapolitica.pdf. Acesso em : 30.abr.2007.

\section{REDE DE PARTICIPAÇÃO POLÍTICA DO}

EMPRESARIADO. s/d. Disponível em : http:/ /www.redeempresarial.org.br/. Acesso em : 30.abr.2007. 


\section{ENTREPRENEURS, DEMOCRATIC INSTITUTIONS AND POLITICAL REFORM}

\section{Paulo Roberto Neves Costa}

This text looks at how presidents of the 40 entities that represent entrepreneurs evaluate the functioning of democratic institutions and perspectives of political reform between the years of 2004 and 2005. Data is aggregated in two ways: on the one hand, for the whole set of entities and on the other, according to the nature of each entity (syndicate or associative), by sector (industry, commerce, agriculture, finance, etc.) and by location and scope (state entities, distinguished by regions, and nationwide ones). Our objectives include, on the one hand, defending the importance of mobilizing this type of variable in analyzing the characteristics of entrepreneurs and their political action and, on the other, verifying the degree of homogeneity of opinions and positions with regard to the following aspects: degree of adhesion to and stance taken regarding democracy as a political regime; the evaluation of working democratic institutions; the political importance that is attributed to social groups and political institutions; views taken on entrepreneurs' political activity regarding the powers that be and, lastly, their position regarding to political reform. In this way we attempt to establish elements for future analysis of patterns of entrepreneurial political action regarding issues of political institutions and the future of democracy in Brazil.

KEYWORDS: entrepreneurs; political reform; corporatism; democracy. 


\section{ENTREPRENEURS, INSTITUTIONS DÉMOCRATIQUES ET RÉFORME POLITIQUE}

\section{Paulo Roberto Neves Costa}

Ce texte analyse comment les présidents de 40 organismes de représentation des entrepreneurs brésiliens évaluent le fonctionnement des institutions démocratiques et la perspective de la réforme politique entre les années 2004-2005. Les données seront intégrées de la façon suivante : d’abord, l'ensemble des organismes, ensuite, leur nature (syndicale ou associative), leur secteur (industrie, commerce, agriculture, finances, etc.) et leur localisation ou leur étendue (organisations locales, repérées par régions, nationales). Les objectifs sont, d'une part, de défendre l'importance de l'utilisation de ce type de variantes dans l'analyse des caractéristiques des entreprises et de leur action politique; d'autre part, de vérifier l'homogénéité des avis et des comportements en penant compte de : la portée de l'adhésion et de l’idée à propos de démocratie en régime politique; l'évaluation des institutions démocratiques mises en oeuvre; l'importance politique attribuée aux groupes sociaux et aux institutions politiques; l'interprétation concernant l'action politique des entrepreneurs à l'égard des pouvoirs établis; et leur position face à la réforme politique. Nous comptons donc dresser des éléments permettant d'analyser plus tard les modèles d'action politique des entrepreneurs face à la question des institutions politiques et de l'avenir de la démocratie au Brésil.

MOTS-CLÉS: entreprise; réforme politique; corporativisme; démocratie. 